\title{
KORUPSI DALAM PERSPEKTIF KONSELING ISLAM: HAKIKAT DAN PENANGANANNYA
}

\author{
Warlan Sukandar \\ STKIP Adzkia Padang \\ (E-mail: wsukandar.ma@gmail.com)
}

\begin{abstract}
Corruption is an act that brings a lot of destruction, both for themselves and the people of the nation. Corruption is immoral and sometimes has become a culture in certain societies. In several countries, including Indonesia and Malaysia, there have been various ways to eradicate corruption. This article tries to test corruption behavior from the scientific perspective of Islamic Psychology, essence and ways to overcome corruption from the scientific perspective of Psychology and Islam. Handling corruption is divided into three aspects, namely; prevention aspects, aspects of action, and aspects of education. The valuation methodology used is content analysis to analyze data obtained from various sources related to the research being conducted. The results of this study found that handling corruption from a preventive aspect can be done by instilling twenty Islamic personality traits with individuals. From the aspect of action can be done in various ways; material sanctions, prison sentences, office dismissals, whips, suspension of certain rights to the death penalty. Whereas from the education aspect handling corruption can be done by providing education to all levels of society about the essence of corruption, instilling anti-corruption and applying anti-corruption behavior.
\end{abstract}

Keyword : Corruption, Islamic Psychology, Essence and Handling

Abstrak

Korupsi adalah tindakan yang membawa banyak kehancuran, baik bagi diri mereka sendiri maupun masyarakat bangsa. Korupsi tidak bermoral dan terkadang telah menjadi budaya dalam masyarakat tertentu. Di beberapa negara, termasuk Indonesia dan Malaysia telah melakukan berbagai cara dalam upaya memberantas korupsi. Artikel ini mencoba untuk menguji perilaku korupsi dari perspektif ilmiah Psikologi Islam, esensi dan cara-cara untuk mengatasi korupsi dari perspektif ilmiah Psikologi dan Islam. Penanganan korupsi dibagi menjadi tiga aspek, yaitu; aspek pencegahan, aspek tindakan, dan aspek pendidikan. Metodologi penilaian yang digunakan adalah analisis isi untuk menganalisis data yang diperoleh dari berbagai sumber terkait dengan penelitian yang sedang dilakukan. Hasil penelitian ini menemukan bahwa penanganan korupsi dari aspek pencegahan dapat dilakukan dengan menanamkan dua puluh ciri kepribadian Islam kepada individu. Dari aspek tindakan dapat dilakukan dengan berbagai cara; sanksi material, hukuman penjara, pemecatan kantor, cambuk, penangguhan hakhak tertentu terhadap hukuman mati. Sedangkan dari aspek pendidikan penanganan korupsi dapat dilakukan dengan cara memberikan edukasi kepada 
semua lapisan masyarakat tentang esensi korupsi, menanamkan antikorupsi dan menerapkan perilaku antikorupsi.

Kata kunci: Korupsi, Psikologi Islam, Essence and Handling

\section{A. Pendahuluan}

Masalah korupsi merupakan sesuatu yang mencemaskan bagi setiap negara di dunia, karena perbuatan ini sangat berdampak terhadap perkembangan kemajuan sebuah negara. The Corruption Perceptions Index (CPI) menunjukkan bahwa angka korupsi masih sangat mengkhawatirkan. Indonesia berada pada urutan ke-114 dari 177 negara di dunia, sedangkan Malaysia berada pada urutan ke-53. ${ }^{1}$ Indonesia masih di bawah peringkat yang diraih sejumlah negara ASEAN lain, yaitu Singapura (5), Brunei (38), Malaysia (53), Filipina (94) dan Thailand (102). Kondisi ini telah menunjukan bahwa rata-rata negara di dunia masih belum mampu lepas dari korupsi. Hanya dua negara (Finlandia dan Selandia Baru) yang sudah mendekati hampir bisa melepaskan diri dari korupsi. Ini berarti bahwa dua negara dari 177 negara di dunia yang benar-benar telah bersih dari perilaku korupsi. Tentunya hal ini sangat menarik untuk dikaji karena pada dasarnya perilaku korupsi terkadang sudah mengurat mengakar dalam budaya sebuah negara. Hal ini memerlukan usaha yang sungguh-sungguh untuk memeranginya, dengan cara melakukan usaha dari berbagai aspek. Korupsi bisa dilihat dari berbagai aspek, antara lain aspek hukum, politik, sosiologi, agama dan aspek lainya. ${ }^{2}$ Karena korupsi juga menyangkut karakter manusia, dan erat kajian kaitannya dengan keilmuan psikologi, maka dalam kajian ini penulis tertarik untuk mengkaji korupsi dari perspektif Psikologi Islam

\section{B. Metodologi}

Kajian ini menggunakan metodologi analisis kandungan (content analysis). Analisis isi (content analysis) adalah penelitian yang bersifat pembahasan mendalam terhadap isi suatu informasi tertulis atau tercetak dalam media massa. Fokus kajian analisis kandungan adalah pada isu-isu terkini,

\footnotetext{
"Corruption Perceptions", diakses dari Index. http://cpi.transparency.org/cpi2013/results/ pada tanggal 1 Januari 2018 Kementerian Pendidikan dan Kebudayaan RI dan Direktorat jenderal Pendidikan Tinggi, Pendidikan Anti-Korupsi Untuk Perguruan Tinggi (Jakarta: Kemendikbud RI, 2011), h. 5
} 
fenomena-fenomena pada masa tertentu yang bertujuan untuk menambah ilmu pengetahuan dalam penyelesaian masalah dan menjelaskan persoalan sosial yang berkaitan dengan analisa yang dilakukan. ${ }^{3}$ Kaitannya dengan kajian ini adalah menganalisis hakikat dan penanganan korupsi dari perspektif Psikologi Islam, yaitu dari aspek pencegahan, tindakan dan pendidikan

\section{Hasil Kajian}

\section{Definisi Korupsi}

Kata "korupsi” berasal dari bahasa Latin, “corruption” (Fockema Andrea: 1951) atau "corruptus" (Webster Student Dictionary: 1960). Selanjutnya dikatakan bahwa "corruptio" berasal dari kata "corrumpere", suatu bahasa Latin yang lebih tua. Dari bahasa Latin tersebut kemudian dikenal dengan istilah “corruption, corrupt" (Inggris), "corruption" (Perancis) dan "corruptie/korruptie" (Belanda). Arti kata korupsi secara harfiah adalah kebusukan, keburukan, kebejatan, ketidakjujuran, dapat disuap, tidak bermoral, penyimpangan dari kesucian.

Di Malaysia perkataan korupsi disebut dengan "resuah". Istilah resuah berasal dari Bahasa Arab yaitu "risywah". Menurut Kamus umum Arab-Indonesia arti risywah sama dengan korupsi (Andi Hamzah: 2002). Risywah (suap) secara terminologi bererti pemberian yang diberikan seseorang kepada hakim atau lainnya untuk memenangkan perkaranya dengan cara yang tidak dibenarkan atau untuk memperoleh kedudukan (al-Misbah al-Munir-al-Fayumi, al-Muhalla-Ibn Hazm). Semua ulama sepakap mengharamkan risywah yang terkai dengan pemutusan hukum, bakan perbuatan ini termasuk dosa besar.

Menurut terminologi Fiqh, Risywah (suap) adalah segala sesuatu yang diberikan oleh seseorang kepada seorang hakim atau yang bukan hakim agar ia memutuskan suatu perkara untuk (kepentingan) nya atau agar ia mengikuti kemauannya. ${ }^{4}$ Sedangkan menurut Ibnu Nadim Risywah adalah segala sesuatu yang diberikan seseorang kepada hakim atau yang lainnya untuk memutuskan

\footnotetext{
${ }^{3}$ Ahmad Sunawari Long, Pengenalan Metodologi Penyelidikan Pengajian Islam, (Bangi: UKM, 2008), h. 26

4 Rofiqul 'A'la, Suap Dalam Perspektif Islam, dalam A.S.Burhan dkk, ed, Korupsi Di Negeri Kaum Beragama; Ikhtiar Membangun Figh Anti Korupsi (Jakarta: P3M dan Kemitraan-Partnership, 2004), h.182
} 
suatu perkara atau membawa (putusan tersebut) sesuai dengan keinginannya (yang memberi).

Firman Allah swt:

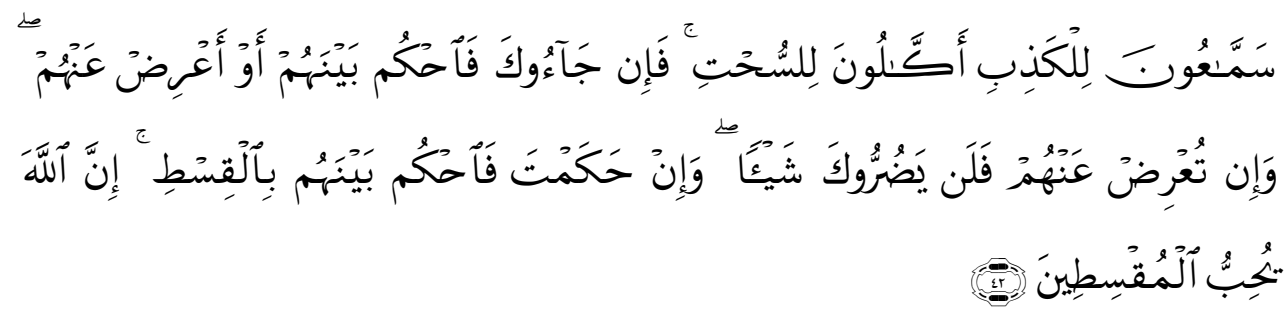

Mereka sangat suka mendengar berita-berita dusta, sangat suka memakan segala yang haram (rasuah dan sebagainya). Oleh itu kalau mereka datang kepadaMu, maka hukumlah di antara mereka (dengan apa yang telah diterangkan oleh Allah), atau berpalinglah dari mereka; dan kalau engkau berpaling dari mereka maka mereka tidak akan dapat membahayakanmu sedikitpun; dan jika Engkau menghukum maka hukumlah di antara mereka dengan adil; kerana Sesungguhnya Allah mengasihi orang-orang yang berlaku adil (QS. Al-Maidah: 42).

Imam al-Hasan dan Said bin Jubair menafsirkan perkataan, لِلسُحْتِ

bermakna Risywah. ${ }^{5}$ Dengan demikian perbuatan korupsi atau risywah merupakan sikap yang identik dengan memakan makanan yang haram (diharamkan mencari suap, menyuap dan menerima suap). Dalam hal ini korupsi merupakan suatu perbuatan yang bususk, jahat dan merusak. Dengan demikian korupsi menyangkut sesuatu yang bersifat moral dan karakter. Al-Quran telah memperingatkan bahwa orang yang memberi suap dan menerima suap adalah sama-sama melakukan perbuatan yang keji dan telah melakukan perbuatan yang busuk dan buruk.

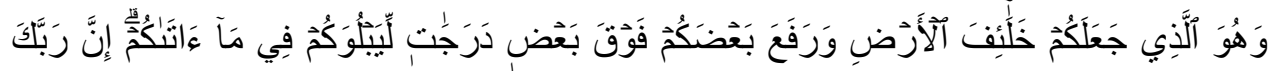

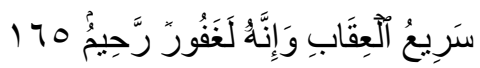

Dan janganlah kamu makan (atau mengambil) harta (orang-orang lain) di antara kamu dengan jalan yang salah, dan jangan pula kamu menghulurkan harta kamu (memberi rasuah) kepada hakim-hakim kerana hendak memakan (atau mengambil) sebahagian dari harta manusia dengan (berbuat) dosa, padahal kamu mengetahui (salahnya) (QS. AlBaqarah: 188).

5 Kementerian Pendidikan dan Kebudayaan RI dan Direktorat jenderal Pendidikan Tinggi. Op. Cit. h.23 


\section{Faktor Penyebab Korupsi}

Beberapa teori telah menjelaskan faktor penyebab terjadinya korupsi, antara lain: teori Means-ends schema yang diperkenalkan oleh Robert Merton. Teori menyatakan bahwa korupsi merupakan suatu perilaku manusia yang disebabkan oleh tekanan sosial, sehingga menyebakan pelanggaran norma-norma. Handoyo mengatakan bahwa setiap sistem sosial memiliki tujuan dan manusia berusaha untuk mencapainya melalaui cara-cara (means) yang telah disepakati. ${ }^{6}$ Dalam mencapai tujuan-tujuan tersebut tidak jarang terjadi tekanan yang menyebabkan banyak orang yang tidak memiliki kesempatan dalam struktur sosial, karena adanya diskriminasi terhadap rasial, etnik, capital, keterampilan dan sebagainya.

Golongan ini kemudian mencari cara untuk mendapatkan pengakuan dirinya dalam masyarakat. Kadang-kadang cara-cara kotor atau menyimpang dari norma masyarakat terpaksan mereka lakukan untuk melawan ketidakadilan yang mereka alami. Dengan demikian teori ini menggambarkan bahwa budaya yang terlalu menekankan dari segi ekonomi tetapi membatasi kesempatan untuk mencapainya, akan menyebabkan tingkat korupsi yang tinggi.

Teori Solidaritas Sosial yang dikembangkan oleh Emile Durkheim (18581917). Teori ini melihat bahwa watak sebenarnya bersifat pasif dan dikendalikan oleh masyarakatnya. Menurut pandangan teori ini, masyarakat mempunyai pengaruh yang lebih besar dalam membentuk perilaku individu dari lingkungannya (kemendikbud, 2011: 46). Dengan demikian dapat disimpulkan bahwa sistem masyarakat yang telah terbiasa korupsi akan membentuk masyarakat yang korupsi pula.

Teori GONE yang di kembangkan oleh Jack Balogne (2006). Menurut teori ini adapun faktor-faktor yang menyebabkan terjadinya korupsi, antara lain:
a. $\operatorname{Keserakahan}($ Greet)
b. Kesempatan (Opportunities)
c. Kebutuhan (Needs)
d. Pengungkapan (Exposure)

${ }^{6}$ B. Hestu Cipto Handoyo, Hukum Tata Negara, (Yogyakarta: Universitas Atmajaya, 2009), h. 55 
Greed, terkait keserakahan para pelaku korupsi. Koruptor adalah orang yang tidak puas terhadap dirinya. Opportunity, sistem yang memberi peluang untuk melakukan korupsi, baik itu individu atau secara berkelompok dan kelembagaan. Needs, yaitu sikap mental yang tidak merasa cukup, dan tidak pernah merasa puas dengan kebutuhan-kebutuhan duniawi. Exposure, hukuman yang yang dijatuhkan kepada koruptor yang tidak memberi efek jera pelaku maupun orang lain. ${ }^{7}$

Jika dilihat dari sisi psikologi, maka faktor penyebab korupsi itu dapat disebabkan oleh faktor internal dan juga faktor eksternal. ${ }^{8}$ Faktor internal merupakan penyebab korupsi disebabkan oleh dorongan dari dalam diri individu. Sedangkan faktor eksternal merupakan penyebab korupsi itu disebabkan oleh dorongan dari luar dirinya.

a. Faktor Internal, meliputi;

1) Aspek perilaku individu

a) Sifat tamak/rakus manusia (Sifat merasa tidak cukup)

b) Moral yang kurang kuat. Moral yang kurang kuat akan menyebabkan mudah tergoda untuk melakukan korupsi

c) Gaya hidup yang konsumtif. "Besar pasak dari pada tiang", suatu pepatah yang menggambarkan kehidupan yang konsumtif. Sikap ini akan muda mengara kepada perilaku korupsi.

2) Aspek sosial. Dorongan keluarga memiliki potensi untuk melakukan korupsi.

b. Faktor Eksternal, meliputi;

1) Aspek sikap masyarakat terhadap korupsi. Budaya masyarakat bisa menimbulkan prilaku korupsi. Kemudian masyarakat juga kurang menyadari bahaya korban korupsi adalah masyarakat itu sendiri. Masyarakat kurang menyadari bila dirinya terlibat korupsi dan seringnya rasa pesimis terjadi ditengah-tengah masyarakat terhadap upaya pemberantasan korupsi.

2) Aspek ekonomi. Terdesak dalam kebutuhan ekonomi sering membuka peluang untuk melakukan korupsi.

7 Kementerian Pendidikan dan Kebudayaan RI dan Direktorat jenderal Pendidikan Tinggi. Op. Cit. h.46-47

${ }^{8}$ Ibid., h.47-49 
3) Aspek politis. Permainan politik yang tidak sehat dalam mencapai kekuasaan berdampak sangat besar terhadap sikap untuk korupsi.

4) Aspek organisasi

a) Kurang ada sikap keteladanan pemimpin

b) Tidak adanya kultur organisasi yang benar

c) Kurang memadai sistem akuntabilitas

d) Kelemahan sistem pengendalian manajemen

e) Lemahnya pengawasan

\section{Bahaya Korupsi dalam Pandangan Islam}

Tidaklah Allah SWT. melarang sesuatu, melainkan di balik itu terkandung keburukan dan mudharat (bahaya) bagi pelakunya. Begitu pula dengan perbuatan korupsi (ghulul), tidak luput dari keburukan dan mudharat tersebut. ${ }^{9}$ diantaranya:

a. Pelaku ghulul (korupsi) akan dibelenggu, atau ia akan membawa hasil korupsinya pada hari Kiamat, sebagaimana ditunjukkan dalam ayat ke-161 surat Ali Imran dan hadits 'Adiy bin 'Amirah Radhiyallahu 'anhu di atas. Dan dalam hadits Abu Humaid as Sa'idi Radhiyallahu 'anhu, Rasulullah Shallallahu 'alaihi wa sallam bersabda :

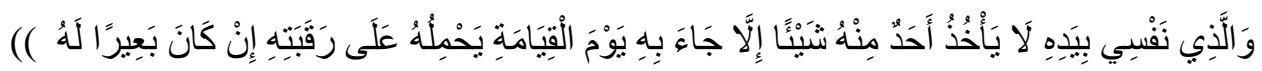

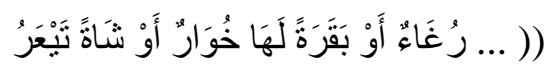

"Demi (Allah), yang jiwaku berada di tanganNya. Tidaklah seseorang mengambil sesuatu daripadanya (harta zakat), melainkan dia akan datang pada hari Kiamat membawanya di lehernya. Jjika (yang dia ambil) seekor unta, maka (unta itu) bersuara. Jika (yang dia ambil) seekor sapi, maka (sapi itu pun) bersuara. Atau jika (yang dia ambil) seekor kambing, maka (kambing itu pun) bersuara ..."

b. Perbuatan korupsi menjadi penyebab kehinaan dan siksa api neraka pada hari

Kiamat. Dalam hadits Ubadah bin ash Shamit Radhiyallahu 'anhu, bahwa Nabi Shallallahu 'alaihi wa sallam bersabda :

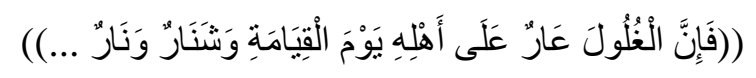

${ }^{9}$ Syaiful, "Korupsi dalam Pandangan Islam", diakses dari: http://www.suaraislam.com/read/index/9012/Korupsi-dalam-Pandangan-Islam, pada tanggal 13 Januari 2018 
"...(karena) sesungguhnya ghulul (korupsi) itu adalah kehinaan, aib dan api neraka bagi pelakunya".

c. Orang yang mati dalam keadaan membawa harta ghulul (korupsi), ia tidak mendapat jaminan atau terhalang masuk surga. Hal itu dapat dipahami dari sabda Nabi Shallallahu 'alaihi wa sallam :

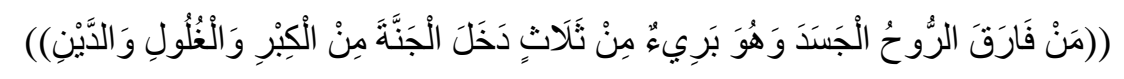

"Barangsiapa berpisah ruh dari jasadnya (mati) dalam keadaan terbebas dari tiga perkara, maka ia (dijamin) masuk surga. Yaitu kesombongan, ghulul (korupsi) dan hutang."

d. Allah SWT. tidak menerima shadaqah seseorang dari harta ghulul (korupsi), sebagaimana dalam sabda Nabi Shallallahu 'alaihi wa sallam :

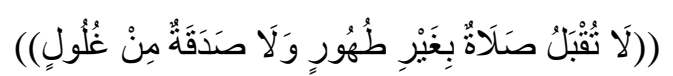

"Shalat tidak akan diterima tanpa bersuci, dan shadaqah tidak diterima dari harta ghulul (korupsi)".

e. Harta hasil korupsi adalah haram, sehingga ia menjadi salah satu penyebab yang dapat menghalangi terkabulnya do'a, sebagaimana dipahami dari sabda Nabi Shallallahu 'alaihi wa sallam :

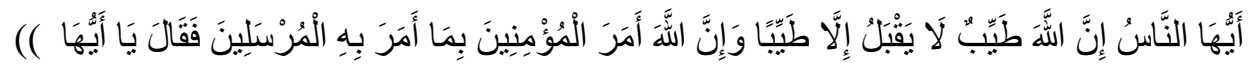

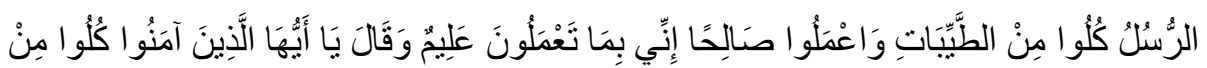

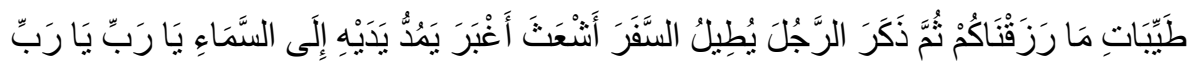

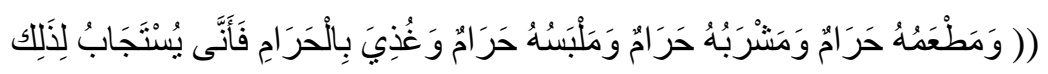

"Wahai manusia, sesungguhnya Allah itu baik, tidak menerima kecuali yang baik. Dan sesungguhnya Allah memerintahkan orang-orang yang beriman dengan apa yang Allah perintahkan kepada para rasul. Allah berfirman,"Wahai para rasul, makanlah dari yang baik-baik dan kerjakanlah amal shalih. Sesungguhnya Aku Maha Mengetahui apa yang kalian kerjakan". Dia (Allah) juga berfirman: "Wahai orang-orang yang beriman, makanlah yang baik-baik dari yang Kami rizkikan kepada kamu," kemudian beliau (Rasulullah) Shallallahu 'alaihi wa sallam menceritakan seseorang yang lama bersafar, berpakaian kusut dan 
berdebu. Dia menengadahkan tangannya ke langit (seraya berdo'a): "Ya Rabb..., ya Rabb...," tetapi makanannya haram, minumannya haram, pakaiannya haram dan dirinya dipenuhi dengan sesuatu yang haram. Maka, bagaimana do'anya akan dikabulkan?"

\section{Bimbingan Konseling Islam dan Perilaku Korupsi}

Bimbingan Islami adalah proses pemberian bantuan terhadap individu agar mampu hidup selaras dengan ketentuan dan petunjuk Allah, sehingga dapat mencapai kebahagiaan hidup di dunia dan di akherat. Sedangkan konseling Islami adalah proses pemberian bantuan terhadap individu agar menyadari kembali akan eksistensinya sebagai makhluk Allah yang seharusnya hidup selaras dengan ketentuan dan petunjuk Allah, sehingga dapat mencapai kebahagian dunia dan akhirat. ${ }^{10}$ Ilmu psikologi Islam merupakan corak psikologi yang berlandaskan citra manusia menurut ajaran Islam, yang mempelajari keunikan dan pola perilaku manusia sebagai ungkapan pengalaman interaksi dengan diri sendiri, lingkungan sekitar dan alam kerohanian dengan tujuan meningkatkan kesehatan mental dan kualitas keberagamaan. ${ }^{11}$ (Jamaluddin Ancok, 1994: 144).

Sehubungan dengan definisi korupsi itu sendiri yaitu kebusukan, keburukan, kebejatan, ketidakjujuran, dapat disuap, tidak bermoral, penyimpangan dari kesucian, maka perilaku korupsi jelas merupakan perilaku tidak sehat atau sakit mental (Psikopatologi) dalam pandangan psikologi Islam. Psikopatologi dalam perspektif Islam dibahas dalam kajian tasawuf dengan konsep akhlak. Akhlak manusia dapat dibagi menjadi dua, yaitu akhlak terpuji (mahmudah) dan akhlak tercela (mazmumah) ${ }^{12}$ Dalam perspektif Islam, penyakit jiwa sering diidentikkan dengan beberapa sifat buruk atau tingkah laku tercela ( $a l$ akhlaq al-mazmumah), seperti sifat tamak, dengki, iri hati, arogan, emosional dan seterusnya.

Zakiah Darajat (1990) menyebutkan bahwa penyakit itu terdiri dari dua macam: pertama, adalah penyakit jiwa yang disebabkan oleh gangguan-gangguan

${ }^{10}$ Thohari Musnamar, Dasar-dasar Konseptual Bimbingan dan Konseling Islami, (Yogyakarta: UII Press, 1992), h.5

h. 144

11 Jamaluddin Ancok, Psikologi Islam, (Yogyakarta: Pustaka Pelajar, 1994),

12 Hardiani, Psikopatologi dalam Perspektif Islam; Hakikat dan Penanganannya. Jurnal Ta`dib Vol. 11, No. 1, h.48 
kejiwaan telah berlarut-larut, sehingga mencapai puncaknya tanpa suatu penyelesaian yang wajar, atau dengan kata lain disebabkan oleh hilangnya keseimbangan mental secara menyeluruh akibat kondisi lingkungan yang sangat menekan, ketegangan batin dan sebagainya: kedua, penyakit jiwa yang disebabkan oleh adanya kerusakan anggota tubuh, misalnya: otak, sentral saraf atau anggota fisik lain untuk menjalankan tugasnya. Hal ini mungkin disebabkan oleh karena keracunan akibat minum-minuman keras, obat-obat perangsang atau narkotik akibat penyakit kotor (sifilis), dan sebagainya. ${ }^{13}$

Hasan Muhammad as-Syarqawi (1979) dalam kitabnya Nahw 'Ilmiah Nafsi, membagi penyakit jiwa dalam sembilan bagian, yaitu: pamer (riya'), marah (al-ghadhab), lalai dan lupa (al-ghaflah wan nisyah), was-was (al-was-wasah), frustrasi (al-ya's), rakus (tama'), terperdaya (al-ghurur), sombong (al-ujub), dengki dan iri hati (al-hasd wal hiqd). Menurut al-Ghazali ada delapan yang termasuk perilaku merusak (al-Muhlikat) yang menyebabkan psikopatologi, yaitu: (1) bahaya perut dan kelamin (seperti memakan makanan subhat atau haram, atau berhubungan seksual yang dilarang); (2) bahaya mulut (seperti mengolok-olok, debat yang tidak berarti, dusta, adu domba, dan menceritakan kejelekan orang lain); (3) bahaya marah, iri dan dengki; (4) bahaya cinta dunia; (5) bahaya cinta harta dan pelit; (6) bahaya angkuh dan pamer; (7) bahaya sombong dan membanggakan diri; dan (8) bahaya menipu. ${ }^{14}$

Menurut Seorang psikiater dengan kekhususan di bidang Psikosomatik dan Psikiatri Liaiso yaitu Dr. Andri, mengatakan bahwa korupsi itu mirip dengan gangguan jiwa. Hal itu akan terlihat dari gejala-gejala dan tanda-tanda sebagai berikut; ${ }^{15}$

a. Tidak Ada Tilikan

Tidak ada tilikan atau insight adalah salah satu gejala gangguan jiwa yang banyak ditemukan pada pasien gangguan jiwa berat seperti skizofrenia. Pasien

\footnotetext{
Zainuddin, "Terapi Jiwa Menurut Islam", Diakses dari http://zainuddin.lecturer.uin-malang.ac.id/2013/11/08/terapi-jiwa-menurut-islam/ pada tanggal 3 Januari 2018

${ }^{14}$ Abdul Mujib dan Jusuf Mudzakir, Nuansa-nuansa Psikologi Islam (Jakarta: PT. RajaGrafindo Persada, 2002), h.178

${ }^{15}$ Diaksesdari(http://health.kompas.com/read/2013/02/01/09360346/Korupsi.itu.Mi rip.Gangguan.Jiwa pada tanggal 8 Januari 2018
} 
skizofrenia yang berat kebanyakan merasa dirinya tidak sakit sehingga tidak memerlukan obat. Pasien juga sering menolak pengobatan karena merasa dirinya baik-baik saja. Pikiran pasien skizofrenia biasanya diwarnai kepercayaan yang salah yang membuatnya menjadi mempunyai keyakinan yang salah juga terhadap sesuatu. Keyakinan yang salah ini yang membuatnya mengalami waham atau delusi.

Koruptor memang sering tidak mempunyai tilikan. Tertangkap basah membawa uang hasil korupsi atau sogokan pun mereka tetap berkelit. Pada banyak kesempatan walaupun bukti kuat telah dikemukakan, koruptor tetap menampik melakukan perbuatan itu. Saya pikir hal ini mungkin dikarenakan konsep apa itu Korupsi masih belum jelas di mata para koruptor. Entah konsep apa yang ada di pikiran mereka tentang korupsi itu. Apakah mengambil uang dan barang yang bukan miliknya itu dibenarkan menurut mereka? Atau mereka beranggapan bahwa korupsi itu tidak salah karena merupakan keuntungan dari posisinya saat ini. Jadi mereka mungkin berpikir kalau mendapatkan keuntungan karena posisinya itu, bukanlah yang termasuk korupsi. Mungkin di pikiran mereka, korupsi atau mengambil uang rakyat itu kalau mereka terang-terangan mengambil uang rakyat di dompet rakyat pada saat kunjungan kerja misalnya.

b. Tidak Merasa Bersalah

Pasien yang mengalami gangguan kepribadian tipe ambang atau dikenal dengan Borderline Personality Disorder sering merasa tidak bersalah jika melakukan sesuatu yang merugikan orang lain. Bagi kebanyakan pasien gangguan kepribadian, masalah bukan pada diri mereka tetapi pada orang lain. Sehingga bagi mereka jika ada masalah antara dia dan orang lain, artinya yang salah ya orang lain. Orang yang melakukan korupsi juga sering sekali merasa tidak bersalah. Mereka merasa apa yang dilakukannya adalah bagian dari pekerjaan mereka. Pendeknya, bukan masalah bagi mereka melakukan korupsi karena memang ada kesempatan itu. Wajar jika sudah tertangkap tanganpun perilaku para koruptor tetap santai dan percaya diri tanpa merasa bersalah sedikitpun.

c. Perlu Hukuman Berat

Dalam ilmu kedokteran jiwa salah satu terapi yang bisa dilakukan untuk mengubah perilaku manusia adalah terapi kognitif (pikiran) dan terapi perilaku. 
Salah satu dasar dari terapi perilaku untuk kasus yang tilikannya kurang adalah menggunakan reward and punishment. Ini artinya memang perlu ada suatu hukuman yang berat yang bisa menjerakan untuk para pelaku korupsi dan caloncalon koruptor agar menjadi jera dan tidak mengulangi perbuatannya. Bagi yang mempunyai kejujuran yang tinggi perlu diberikan penghargaan yang tinggi. Walaupun sebenarnya kejujuran adalah bagian dari amanah untuk melakukan tugas yang dibebankan oleh masyarakat kepada para orang-orang terpercaya ini.

Berdasarkan uraian di atas maka jelas bahwa perilaku korupsi merupakan penyakit mental. Dalam perbuatan korupsi terdapat perbuatan-perbuatan yang tidak baik, seperti tidak jujur, suka menipu, merasa tidak puas, terlalu cinta dunia, memakan makanan yang haram dan lain sebagainya. Perbuatan-perbuatan tersebut terangkum dalam satu perbuatan yaitu, korupsi. Sehingga dapatlah dikatakan bahwa mereka perbuatan korupsi merupakan perbuatan seseorang yang sakit mental.

\section{Penanganan Korupsi dari Perspektif Konseling Islam}

Merujuk kepada faktor-faktor yang menyebabkan terjadinya korupsi sebagaimana yang telah diuraikan di atas, dapat dikatakan bahwa secara psikologi penyebab korupsi disebabkan oleh faktor internal dan faktor eksternal. Faktor internal merupakan faktor korupsi yang datangnya dari dalam diri peribadi atau individu, sedangkan faktor eksternal merupakan penyebab korupsi yang datang dari luar diri individu. Beranjak dari hal ini maka upaya pencegahan dapat dilakukan dengan cara mengilangkan, atau setidaknya mengurangi kedua faktor penyebab korupsi tersebut.

Hal ini sesuai dengan pendapat al-Ghazali:

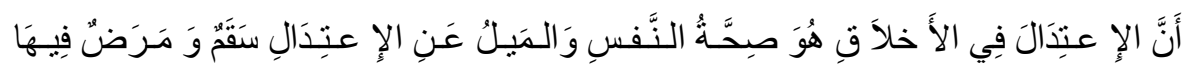

"Menegakkan akhlak (yang baik) merupakan kesehatan mental, sedangkan berpaling pada penegakkan itu berarti suatu neurosis dan psikosis. "16

Abdul Mujib dan Jusuf Mudzakir dalam ulasannya mengatakan kutipan tersebut menunjukan bahwa bentuk penanganan penyakit mental menurut alGhazali adalah dengan cara meninggalkan semua perilaku yang buruk dan rendah,

${ }^{16}$ Abdul Mujib \& Jusuf Mudzakir, Op. cit., h.216-217 
yang mengotori jiwa manusia, serta melaksanakan perilaku yang baik untuk membersihkannya. Perilaku yang baik dapat menghapus, menghilangkan dan mengobati perilaku yang buruk. Upaya seperti ini dapat menjadikan jiwa manusia suci, bersih, dan fitri sebagaimana dilahirkan dari rahim ibunya.

Menurut Yahya Jaya ada tiga langkah yang dapat ditempuh untuk mendapatkan kesehatan jiwa. Ketiga langkah tersebut adalah pencegahan (preventif), pengobatan (kuratif) dan pembinaan (kontruktif). ${ }^{17}$ Hal yang sama juga dikemukan oleh Achmad Mubarok bahwa dalam menangani sesuatu masalah maka ada empat pendekatan dalam konseling agama yang bisa dilakukan, yaitu; konseling sebagai langkah pencegahan (preventif), konseling sebagai langkah kuratif, konseling sebagai langkah pemeliharaan, dan konseling sebagai langkah pengembangan. ${ }^{18}$

Sesuai dengan fungsinya, maka setidaknya ada tiga langkah yang bisa dilakukan dalam konseling;

\section{a. Upaya Pencegahan (preventif)}

Upaya pencegahan dapat dilakukan untuk mencegah supaya korupsi tidak terjadi. Upaya ini bisa dilakukan dengan cara menanamkan nilai-nilai anti korupsi kedalam jiwa individu. Adapun nilai-nilai anti korupsi tersebut yakni menanamkan karakter-karakter Islam kedalam diri seseorang. Ada 20 macam kepribadian Islam yang perlu ditanamkan kedalam diri individu dalam upaya mencegahnya agar tidak melakukan korupsi, yaitu: ${ }^{19}$

1) Karakter ta $i b$ (taubat)

Karakter taubat adalah karakter yang menyesal karena melakukan kesalahan (dosa), itu kesalaan kepada Allah SWT maupun kesalaan sosial. Karakter taubat tidak hanya berlaku untuk orang yang melakukan dosa saja, tetapi juga berlaku untuk orang yang bersih, karena taubat juga berfungsi untuk pengembangan diri agar lebih baik.

2) Karakter zahid (zuhud)

\footnotetext{
17 Hardiani. Op. cit., h.51

18 Achmad Mubarok, Konseling Agama Teori dan Kasus, (Jakarta: Bina Rena Pariwara, 2000), h.91-92

19 Abdul Mujib, Kepribadian dalam Psikologi Islam, (Jakarta: PT. RajaGrafindo Persada, 2007), h.309-348
} 
Karakter zuhud adalah karakter yang tidak terpedaya oleh keduniaan. Zuhud bukanlah karakter yang benci dunia dan menyukai hidup susah, namun zuhud adalah tidak merasa gembira dengan harta benda yang dimiliki dan tidak bersedih ketika kehilangan.

3) Karakter wari (warak)

Warak ialah karakter menjaga perbuatan dari perbuatan yang tidak patut yang dapat menurunkan derajat dan kewibawaan diri seseorang.

4) Karakter kha if (khawf)

Karakter khawf adalah karakter yang takut akan kemurkaan Allah SWT akibat melanggar larangan-laranganNya, takut akan kebesarranNya (Q.S. Nuh: 13).

\section{5) Karakter raji (raja`)}

Karakter raja`adalah karakter yang berharap terhadap sesuatu kebaikan kepada Allah SWT dengan disertai usaha yang sungguh-sungguh dan tawakal.

6) Karakter mukhlash (ikhlas)

Karakter ikhlas adalah karakter yang murni dan taat yang seluruh amalnya hanya ditujukan kepada Allah SWT semata, dengan cara membersihkan perbuatan, baik lahir maupun batin dari perhatian makhluk.

7) Karakter Istiqamah (Mustaqim)

Karakter istiqamah adalah karakter individu yang melakukan suatu pekerjaan yang lurus secara kontinue dan abadi.

8) Karakter shabir (sabar)

Karakter sabar yaitu karakter yang mampu menaan diri atau mengendalikan diri. Dalam hal ini tentunya diarapkan mampu menahan diri dari berperilaku korupsi.

9) Karakter mutawakkil (tawakal)

Karakter tawakal adalah karakter menyerahkan diri sepenuhnya kepada Allah SWT, sehingga dalam hatinya tidak ada lagi beban psikologis yang dirasakan.

10) Karakter qani` (qana`ah)

Karakter qana`ah adalah karakter menerima apa adanya. Karakter ini akan menuntut individu untuk mengerahkan segala daya dan upayanya seoptimal 
mungkin, kemudian dia menerima hasil jerih payahnya, tetapi dia belum mampu mencapai keinginannnya, namun dia tidak merasa gagal.

11) Krakter radhi (ridha)

Karakter rida akan melahirkan individu yang rela terhadap apa yang dimiliki dan diberikan dan tidak menuntut lebih, apalagi dengan cara jalan yang haram.

12) Karakter syakir (bersyukur)

Karakter syukur adalah karakter yang menampakkan nikamat Allah SWT yang diberikan kepadanya. Karakter ini akan menjauhkan seseorang dari sifat tamak yang akan mengarah kepada tindakan korupsi.

13) Karakter malu (haya')

Karakter malu adalah kepekaan diri yang medorong individu untuk meninggalkan keburukan dan menunaikan kewajiban. Menanamkan karakter malu dalam diri seseorang akan menjadikan seseorang itu merasa enggan berbuat keburukan (korupsi), karena suda tertanam didalam dirinya apabila dia melakukan keburukan maka dia akan merasa malu kepada Allah SWT, dan juga malu kepada diri sendiri dan juga orang lain.

14) Karakter shadiq (jujur)

Korupsi muncul dari sifat ketidakjujuran dalam sesuatu hal, orang yang tidak jujur dikenal dengan pembohong. Sifat jujur (Shadiq) merupakan sala satu dari sifat Nabi Muhammad SAW. Jujur yaitu kesesuian antara yang diucapkan dengan kejadian yang sesungguhnya, kesesuaian antara yang dihati dengan yang ditampakkan, dan perkataan yang benar ketika berhadapan pada orang yang ditakuti atau diharapkan (Abdul Mujid, 2007: 335).

Benih-benih ketidakjujuran dalam diri merupakan awal dari perilaku korupsi. Banyak perbuatan-perbuatan yang tidak jujur yang kita temukan ditengah-tengah masyarakat, dan termasuk dikalangan pelajar. Sikap pelajar yang suka mencontek merupakan sikap yang tidak jujur dan hal ini berpotensi untuk korupsi yang lebih besar. Selain itu seorang pelajar juga membantu temantemannya dalam ujian dengan cara memberi kunci jawaban kepada temannya. Dan hal ini tentulah sama, karena orang yang menerima dan orang yang memberi sama-sama melakukan perbuatan yang tidak bermoral. 


$$
\text { و المبد اللهي بن عمرو قابن حبان) سمعت رسول الله صلى الله عليه وسلم يقول: لعن الله الراشي }
$$

Dari Abdullah ibn Amru berkata: Saya mendengar Rasulullah Saw. bersabda: Allah melaknat orang yang menyuap dan yang menerima suap. (H.R. Ibnu Hibban).

Jika sudah tertanam sifat jujur dalam dirinya maka sifat ini akan membawa kepada perilaku yang benar dan tidak mau melakukan penyimpangan dalam bekerja. Sifat jujur juga akan membawa seseorang kepada lima keutamaan, yaitu jujur akan mengantarkan kesurga, jujur akan melahirkan ketenangan, jujur disukai banyak orang, jujur akan mengantarkan seseorang kepada derajat yang tinggi dan jujur akan mengantarkan seseorang pada keberkahan hidup.

Firman Allah SWT:

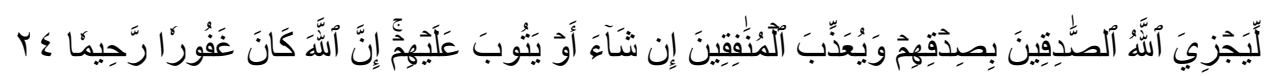

"(Berlakunya yang demikian) supaya Allah membalas orang-orang yang benar disebabkan kebenaran mereka, dan menyeksa orang-orang yang munafik jika ia kehendaki, atau ia menerima taubat mereka. Sesungguhnya Allah adalah Maha Pengampun, lagi Maha Mengasihani." (QS. Al-Ahzab: 24).

\section{5) Karakter mu`tsir (itsar)}

Karakter mu`tsir, yaitu karakter yang mementingkan atau mendahulukan kepentingan orang lain daripada kepentingan dirinya sendiri.

16) Krakter muthawadhi` (tawaduk)

Karakter tawadhuk yaitu sikap qalbu yang tenang, berwibawa, rendah hati, lemah lembut tanpa disertai rasa jahat, congkak dan sombong.

17) Krakter mu`ri (maru`ah)

Karakter mu`ri` adalah karakter keperwiraan yang menjunjung tinggi sifatsifat kemanusiaan yang agung. Karakter mu`ri akan melahirkan individu yang memiliki pengamalan perilaku yang baik dan meninggalkan perilaku yang buruk dan menghindarkan diri dari perbuatan yang hina dan rendah.

18) Karakter muhhib (mahabbah)

Karakter maabbah yaitu kelekatan jiwa individu pada individu yang lain yang didukung oleh perasaan saling memperhatikan, mempercayai dan mendekat, 
sehingga keduanya ingin tetap bersatu, baik lahir maupun batin. Karakter ini akan melahirkan individu yang merasa prihatin terhadap kondisi orang lain akibat perbuatan korupsi.

19) Karakter mukhbit (kerendahan hati)

Karakter mukhbit adalah karakter yang memiliki kerendahan dan kelembutan hati, merasa tenang dan khusyuk dihadapan Allah SWT, dan tidak menganiaya orang lain.

20) Karakter muttaqi` (takwa)

Karakter muttaqi merupakan puncak dari segala karakter, yaitu karakter yang takut terhadap murkanya Allah SWT.

Firman Allah SWT:

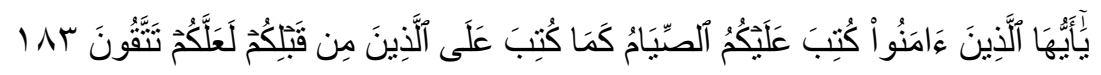

Wahai orang-orang yang beriman! Kamu diwajibkan berpuasa sebagaimana diwajibkan atas orang-orang yang dahulu daripada kamu, supaya kamu bertaqwa (QS. Al-Baqarah: 183).

Ibnu Katsir dalam menafsirkan ayat ini menyebutkan arti takwa dengan melemahkan daya-daya syahwat agar diri tidak berbuat maksiat. Sedangkan alQurthubi memaknai takwa dengan jalan mempersempit diri untuk menempu jalan yang dilalui setan.

\section{b. Upaya Penindakan (kuratif)}

Dalam pidana korupsi, sanksi yang diterapkan bervariasi sesuai dengan tingkat kejahatannya. Mulai dari sanksi material, penjara, pemecatan jabatan, cambuk, pembekuan hak-hak tertentu sampai hukuman mati. Mengapa bervariasi? Karena tidak adanya nash qath'i yang berkaitan dengan tindak kejahatan yang satu ini. Artinya sanksi syariat yang mengatur hal ini bukanlah merupakan paket jadi dari Allah swt. yang siap pakai. Sanksi dalam perkara ini termasuk sanksi ta'zir, di mana seorang hakim (imam/pemimpin) diberi otoritas penuh untuk memilih tentunya sesuai dengan ketentuan syariat-bentuk sanksi tertentu yang efektif dan sesuai dengan kondisi ruang dan waktu, di mana kejahatan tersebut dilakukan. $^{20}$

${ }^{20}$ Rafiqul A`la, Op. cit., h. 199 
Apabila para fuqaha dalam hukum pidana Islam konvensional (fiqh aljinayat al-fiqh al-jinai) memasukkan ghulul dalam kategori tindak pidana (jarimah) ta'zir yang besar-kecilnya hukuman ('uqubah) diserahkan kepada pemerintah dan hakim, hal itu dapat dipahami, mengingat kejahatan ghulul masih dalam skala kecil yang belum menjadi ancaman berarti. Hanya saja perlu digaris bawahi bahwa hukuman ta'zir kendatipun pada asalnya bertujuan untuk memberi pelajaran (lil al-ta'dib) bentuknya tidak harus selalu berwujud hukuman ringan. Seperti yang ditulis oleh Abd al-Qadir Awdah dalam Al-Tasyri' al-Jinai al-Islami, banyak fuqaha yang membolehkan pidana ta'zir dalam bentuk hukuman mati jika kepentingan umun menghendakinya (idza iqtadlat al-mashlahah al-'ammah taqrir 'uqubah al-qatl). Dengan memerhatikan kepentingan umum yang terancam dengan sangat serius oleh kejahatan korupsi saat ini, maka dijatuhkannya hukuman ta'zir yang paling keras (hukuman mati) atas para koruptor kelas kakap dapat dibenarkan oleh Islam. ${ }^{21}$

\section{c. Upaya Edukasi Terhadap Masyarakat}

Fungsi edukasi merupakan upaya yang sangat penting untuk dilakukan dalam hal mengatasi korupsi. Edukasi dilakukan kepada semua lapisan masyarakat, dengan tujuan agar mereka memiliki ilmu pengetahuan mengenai tindakan korupsi. Dari upaya edukasi masyarakat diharapkan:

1) Memiliki rasa kepedulian terhadap kondisi yang sedang dihadapi, yaitu korupsi yang sudah kronis.

2) Melakukan kontrol sosial pada setiap kebijakan mulai dari pemerintah terendah hingga kepemerintahan pusat.

3) Masyarakat secara kognitif memiliki pengetahuan tentang hakikat korupsi, secara afektif mempunyai karakter yang anti korupsi dan secara psikomotor memiliki perilaku anti korupsi.

\section{Kesimpulan}

Diakhir penulisan kajian ini dapatlah disimpulkan bahwa korupsi merupakan suatu tindakan yang sangat merugikan berbagai pihak, baik diri

21 Malik Madani, diakses dari 2007: http://www.nuantikorupsi.or.id/page.php?display=dinamis\&kategori=3\&id=192, pada tanggal 8 Januari 2018 
sendiri, keluarga, masyarakat dan negara. Oleh karena tindakan korupsi merupakan perbuatan yang busuk, buruk, bejat, ketidakjujuran, dapat disuap, tidak bermoral, penyimpangan dari kesucian maka ciri-ciri ini sama persisnya dengan ciri-ciri mental yang tidak sehat. Maka dapatlah dismpulkan bahwa koruptor dalam pandangan Psikologi Islam termasuk kepada orang yang mempunyai penyakit pada pada mentalnya. Psikologi Islam memiliki konsep yang jelas dalam menanggulangi penyakit korupsi, yaitu dilakukan dengan tiga aspek ; pencegahan, tindakan dan pendidikan. Setelah diperhatikan dari upaya-upaya yang ditawarkan oleh Psikologi Islam dalam meananggulangi perbuatan korupsi, ternyata Psikologi Islam memiliki konsep penanganan yang cukup bagus terhadap kasus korupsi. Apabila cara-cara tersebut bisa diterapkan, maka penulis yakin bahwa kasus korupsi akan semakin bisa dikurangi dan bukan suatu yang mustahil dapat dilenyapkan. 


\section{Daftar Pustaka}

Abdul Mujib dan Jusuf Mudzakir. 2002. Nuansa-nuansa Psikologi Islam. Jakarta: PT. RajaGrafindo Persada.

Abdul Mujib. 2007. Kepribadian dalam Psikologi Islam. Jakarta: PT. RajaGrafindo Persada

Abu Hatim Muhammad Ibn Hibban Ibn Ahmad al-Tamimy, Shahih Ibn Hibban (Beirut: Muassasah al-Risalah, 1414 H/ 1993 M), j. 11, s. 468.

Achmad Mubarok. 2000. Konseling Agama Teori dan Kasus. Jakarta: Bina Rena Pariwara.

Ahmad Sunawari Long. 2008. Pengenalan Metodologi Penyelidikan Pengajian Islam. Bangi: UKM.

Andri. 2013. Korupsi Itu Mirip Gangguan Jiwa? (atas talian) http://health.kompas.com/read/2013/02/01/09360346/Korupsi.itu.Mirip.Ga ngguan.Jiwa (2 Juni 2014).

Corruption Perceptions Index 2013. http://cpi.transparency.org/cpi2013/results/ (1 Juni 2014)

H. A. Malik Madany, Korupsi SebagaiKejahatan Terhadap Kemanusian Dalam Perspektif Islam, (atas talian) http://www.nuantikorupsi.or.id/page.php?display=dinamis\&kategori=3\&id=192 (2 Juni 2014)

Handoyo, B. Hestu Cipto. Hukum Tata Negara. 2009. Yogyakarta: Universitas Atmajaya

Hardiani. 2008. Psikopatologi dalam Perspektif Islam; Hakikat dan Penanganannya. Jurnal Ta`dib Vol. 11, No. 1

Hasan Muhammad al-Syarqawy. 1997. Nahw al-Nafs al-Islamy. Iskandaria: alHai at at al-Mishriyyah.

Jamaluddin Ancok. 1994. Psikologi Islam, Yogyakarta: Pustaka Pelajar

Kementerian Pendidikan dan Kebudayaan RI dan Direktorat jenderal Pendidikan Tinggi. 2011. Pendidikan Anti-Korupsi Untuk Perguruan Tinggi. Jakarta: Kemendikbud RI

Rofiqul 'A'la, "Suap Dalam Perspektif Islam," dalam A.S.Burhan dkk, ed, Korupsi Di Negeri Kaum Beragama; Ikhtiar Membangun Fiqh Anti Korupsi (Jakarta: P3M dan Kemitraan-Partnership, 2004).

Syaiful. 2013. Korupsi dalam Pandangan Islam. (atas talian) http://www.suaraIslam.com/read/index/9012/Korupsi-dalam-Pandangan-Islam $\quad(2$ Juni 2014).

Zainuddin. 2013. Terapi Jiwa Menurut Islam. (atas talian). http://zainuddin.lecturer.uin-malang.ac.id/2013/11/08/terapi-jiwa-menurutislam/ (3 Juni 2014). 